\title{
Deviant Women: Transgressing Interactional Rules
}

\author{
Jennifer J. Peck ${ }^{1}$ \\ ${ }^{1}$ Department of Linguistics, Faculty of Human Sciences, Macquarie University, Sydney, Australia \\ Correspondence: Jennifer J. Peck, Department of Linguistics, Faculty of Human Sciences, Macquarie University, \\ Sydney, NSW, 2109, Australia. E-mail: Jennifer.Peck@mq.edu.au
}

Received: April 6, 2013 Accepted: August 5, 2013 Online Published: September 23, 2013

doi:10.5539/ijel.v3n5p1

URL: http://dx.doi.org/10.5539/ijel.v3n5p1

\begin{abstract}
Everyday conversation appears to proceed unproblematically: the rules of interaction are taken for granted and shared by participants. This paper examines data from same- and mixed-sex conversations which show that linguistic practices are constantly at play in interaction, asserting that there are rules and controlling transgressions from implicit norms. Covert features such as silence, interruption and overt criticism are revealed as powerful strategies for determining who will speak and to imply stylistic value. The paper discusses the enactment of micropolitical social practices in informal talk, and argues that these practices may function to maintain a dominant status quo.

Some theories claim that the styles of talk of women and men differ, with women's talk featuring shared floors and men's sole-speaker floors. This stylistic difference has implications for the meanings of overlapping speech, with overlap being preferred in female, but not in male speech. The data show that transgressions of dominant discursive rules are negatively sanctioned, with censure resulting in silence or withdrawal from the speaking floor.
\end{abstract}

The analysis and discussion draw on theories from linguistics, ethnomethodology and sociology, commenting on seminal work and ongoing debates and demonstrating the value of a critical interdisciplinary approach.

Keywords: gender, language, interaction, rules, conversation, silence, interruption, overlap

\section{Introduction}

\subsection{Overview}

Extensive research and debate into issues of gender and language have produced lively and insightful discussions in linguistics and in psychology, sociology, critical feminist theory, and philosophy. Much early research, some prompted by Lakoff's (1975) seminal work, explores ways in which linguistic systems are used to discriminate against women or restrict the language available for women to use (e.g., Coates, 1989; Graddol \& Swann, 1989; Pauwels, 1998; Spender, 1980a,b; Thorne, Kramarae \& Henley, 1983). According to this research, social structures that ensure male dominance are responsible for the construction of women as a subordinate group, and for the resulting interpretation of their linguistic performance as deficient. Some research argues that different socialization processes result in gender-differentiated linguistic performances (e.g., Cook-Gumperz, 1992, 1995; Hodge \& Kress, 1988; Maltz \& Borker, 1982; Peck, 2000). The 'difference' and 'dominance' models have been extensively debated, and feminist theory both critiques previous literature and proposes new approaches to the analysis and interpretation of the relevance and performance of gender (see e.g., Baxter, 2003; Speer, 2005; Weatherall, 2002).

This research project examined data from same- and mixed-sex conversations to discover how interactional rules were made relevant, and whether preferred rules and rituals were associated with features such as power or gender. The relationship between dominant interactional norms and gender is examined in detail here, and it is argued that linguistic enactments of micro-societal control function to maintain a status quo at the macro-societal level. The analysis and discussion draw on theories from linguistics, ethnomethodology and sociology, commenting on seminal work in these fields and demonstrating the value of a critical interdisciplinary approach.

\subsection{Theoretical Models}

Early research that argues for the 'different cultures' approach is Maltz and Borker's (1982) work which claims that girls and boys belong to different (sub)cultures, and that the language used in groups of girls or boys 
demonstrates boys' orientation towards hierarchical, competitive communication, and girls' towards negotiation and cooperative linguistic strategies. This analysis is intuitively appealing, and has strong explanatory potential for gender-differential conversation and behaviour. The difference approach is arguably evident in some of Coates's and Holmes's work which demonstrates that women and men have different communication strategies; women's talk being oriented towards modalization, concern for the addressee and shared floors, and men's talk being competitive, linear and individualistic (e.g., Coates, 1986, 1996; Holmes, 1984, 1986; see also Falk, 1980; Peck, 2006; Sheldon, 1996a,b; Tannen, 1987, 1990). This theory is critiqued for encouraging sex-stereotyping (see discussion in Weatherall, 2002) and ignoring or supporting male-dominated social structures (e.g., Aries, 1996; Freed \& Greenwood, 1996; Uchida, 1992; Weatherall, 2002). The different cultures model is also seen as being suggestive of 'natural' and pre-existing dichotomous gendered identities, and thus failing to take into account the multiplicity of performances of gender available to all interactants. Speer (2005, p. 47) claims that authors such as Lakoff, Spender and Tannen, working within the difference model, 'have a tendency to imply that speakers have no agency'. If gender is indeed proposed as 'natural', change is necessarily problematized. Coates, however, effectively addresses the essentialist critique by stating that 'we now have a reasonably clear idea of the speaking practices of women' (referring to Coates, 1996; Holmes, 1995), but adding that "talking like a woman' is something speakers learn to do, not something we are born with' (1999, p. 123).

Proponents of the dominance model argue that status rather than sex or gender determines how language will be used, and research finds that linguistic features analysed as being used differently by women and men in fact vary according to the relative power of the speaker (e.g., Aries, 1997; Eakins \& Eakins, 1978; Leet-Pellegrini, 1980; O'Barr \& Atkins, 1980). One risk of the foregrounding of status may be to minimize the social relevance of gender and its relation to hierarchical power. Thorne (2001, p. 11) engages with issues of hierarchical power, and neatly states: 'There is ample evidence that those with greater power are more likely to interrupt, initiate touch, stare at, and violate the space of those with lesser power'. Since wider social structures effectively preserve gendered micropolitical (Henley, 1977) communicative enactments, it seems, as this paper shows, more likely that men will interrupt and violate the speaking space of women.

Feminist debates emphasize the multiplicity of possible identity enactments, foregrounding the options available through perfomativity (Butler, 1990a,b, 1997), rather than the constraints that may be seen as implied in some accounts of gendered socialization (e.g., Cook-Gumperz, 1992, 1995; Hodge \& Kress, 1988; Peck, 2000) and 'doing gender' (e.g., Lorber \& Farrell, 1991a,b; West \& Zimmerman, 1991; see also Garfinkel, 1967). References to sex status and patriarchy are considered by some to be irrelevant to third wave feminism's discussions (see for example discussion in Baxter, 2003), though these issues may be required to explain the androcentricity of normative rules and the controlling power of male critiques of female performances. Tannen $(1999$, p. 222) claims that gender is relevant, and that the difference and dominance approaches are not mutually exclusive and opposed to each other, but rather that 'dominance relations and cultural relations of all types...are at play in every moment of interaction'.

A key concern of ethnomethodology is to examine both the rules and rituals that participants take for granted (Denzin, 1971, p. 271) and the ways that members of a society assert that there are rules (Zimmerman \& Wieder, 1971, p. 294). This paper shows that deviations from 'taken-for-granted' (Schutz, 1962, p. 55) features are subject to challenge, and deviations may undermine the reciprocal trust (Garfinkel, 1967, p. 50) on which social interaction depends. A point that may be unstated in some sociology, ethnomethodology and conversation analysis literature is that the rules and rituals on which mixed-sex interaction is based are arguably derived from taken-for-granted androcentric norms.

This paper shows how rules are 'at play' in interaction, and how microlinguistic strategies assert the existence of, and control performance in line with interactional rules.

\section{Method}

\subsection{Outline of the Project}

This project examined data from mixed-sex and same-sex conversations to discover whether some features were considered normative in mixed-sex conversation, and how stylistic appropriateness was marked. It has been claimed that interruption is a gender-differentiated strategy, with men using interruption to compete for a sole speaking turn (Spender 1980a), while women's simultaneous or overlapping speech (Coates \& Cameron, 1989; Edelsky, 1981; Falk, 1980; Hirschman, 1973) is collaborative, and is iconic of shared experience. Overlapping speech is essential to the 'melded' (Coates, 1996) or 'ensemble' (Tannen, 1989) floor, in which women speak at the same time and complete each other's utterances. Interruption is arguably of particular interest because it can be used as a floor-taking strategy, and this may correlate with power or status (Eakins \& Eakins, 1978; West, 
1984). In the data examined for this project, overlapping speech was found to be used gender-differentially and covert and overt linguistic strategies were employed by participants to determine who would speak, and to mark non-preferred style. Sections of data that were representative of wider performances and transcriptions are analysed in detail in this paper.

\subsection{Participants}

The participants were dyads or small groups of friends, who were joined on occasion by others who were sometimes previously unknown to some members of that group. Some participants were present in only one recording while others appeared in a number of sessions. The maximum number in any group was six people. Because of the situations, subjects joined groups, sometimes only briefly.

The 47 participants in this study were 20 men and 27 women. Nationalities included Australian, British, Canadian, German, Hungarian, Italian and Polish. Two male participants were working class. Four of the female participants are from working class backgrounds and self-identify as working class, though some analyses might assign them middle class status based on their educational background. The main age demographic was 22-35: the age range of participants was 19-55, with 31 participants being aged between 22-35. Within this central age demographic, there were four lesbian and five gay participants, according to their self-identification.

\subsection{Data and Methodology}

The data were drawn from 30.5 hours of recordings of casual conversation: the naturally-occurring conversation between friends and acquaintances. Recordings were made in a range of social contexts that took place in Queensland, Australia. Some of the recordings were of prearranged meetings of friends for coffee or supper at their homes or in cafés, some were from chance encounters in common social spaces such as canteens at university, or sitting on the grass on campus. A small battery-operated audio recorder was used, and was placed in the centre of the group, usually on a table.

Conversation seemed to proceed without participants being concerned about the fact that they were being recorded. Talk was remarkably uninhibited, with intimate personal details and disagreements often being revealed. This suggests that 'natural' conversation was being recorded. Evidence that people forgot that they were being recorded came from the comments that were sometimes made when they did remember. Remarks such as Oh God, that thing's not on is it?; You're not recording this, are you? occurred, but none of the participants chose to have their contribution erased. The project received ethics approval from The University of Queensland and participants completed consent forms.

A discourse analysis approach was applied to the data, and theories from sociology and enthnomethodology were also used in the explications. The linguistic features analysed here are representative of the data from the project's participants from a range of nationalities, different ethnic and class backgrounds, and having different sexual orientations. It has also been reported to the researcher that similar features to the gender-differential patterns described here occur in the talk of Armenian, Iranian, Korean, Lebanese, and Philipino men and women. (Note 1)

The researcher acknowledges an egocentric socially and politically oriented perspective in reading the data (see Crawford, 1995; Harding, 1986; Speer, 2005; Weatherall, 2002). In the interests of self-reflexivity and exploring the political position brought to the data, the writer has undertaken alternative analyses of some data, drawing on conversation analysis.

\subsection{Transcription Conventions}

The transcription technique used aims to give a sense of the way each conversation is constructed, and in particular to highlight the use and functions of overlapping speech, interruption, and loud or emphatic speech. When it is particularly significant to the discussion, additional paralinguistic information is given in square brackets, for example [laughter]; [enthusiastically]. Symbols used in the transcriptions are given at the end of the article.

\section{Results and Discussion}

\subsection{Negative Sanction of Deviant Behaviour}

Garfinkel (1967) and Schutz (1962) claim that social actors believe that they have similar expectations about communicative processes. It follows that behaviour which appears to deviate from these expectations can be highly confrontational. The negative sanction of perceived deviations typically produces a behavioural shift by the 'offending' party, and this modification facilitates the assumption that behavioural norms are jointly held. The data in this study show that in mixed-sex conversation men correct women's linguistic behaviour when it 
threatens their assumption that understandings about conversational behaviour are reciprocal. While performance of identity is always in a state of flux in interaction, it seems that gender is made relevant in these mixed-sex interactions and this relevance functions to support reciprocity. The preservation of the notion of reciprocity is arguably aided by learned gendered performances: men use competitive strategies to assert the validity of their style as normative, and women's learned cooperation leads them to acquiesce to male controls and modify their style.

Negative sanction may be enacted covertly or overtly, and control that is performed through micro-linguistic behaviour is often unobserved by 'everyday' social actors. Covert sanction is powerful precisely because the strategies used conceal the enactment of the social control that they perform.

\subsubsection{Covert Sanction: Silencing as Power}

The silencing of conversational actors often conceals powerful action (see e.g., DeFrancisco, 1991; Herring, Johnson \& DiBenedetto, 1992, 1995; Tannen \& Saville-Troike, 1985). In the following examples a number of women and men are engaged in casual conversation. The women's overlapping turns are silenced by one of the male actors.

In transcript 1) three of the four participants are discussing Chomsky's movie 'Manufacturing Consent' and his appearance on 'Lateline', a current affairs program on Australian television. 'Romper Stomper' is the title of an Australian film, unrelated to Chomsky's movie or 'Lateline'. The women's talk is rapid and enthusiastic:

$\begin{array}{ll}\text { 1) } 1 & \text { Have you seen this Noam Chomsky movie? } \\ \text { M1 } & \text { No. |Did you see him on 'Lateline'? } \\ \text { M2 } & \quad \text { II saw 'Romper Stomper'. } \\ \text { F1 } & \text { (?? After the reaction ??) } \\ \text { M1 } & \text { (??) } \\ \text { F2 } & \text { Is the film on again? } \\ \text { F1 } & \text { Yeah, it's on this weekend. } \\ \text { F2 } & \text { Oh, have they brought it back? } \\ \text { F1 } & \text { Yeah |(???) } \\ \text { F2 } & \quad \mid \text { Where's it|on? } \\ \text { F1 } & \quad \text { It's on at the Resistance }\end{array}$

|Centre.

F2 $\mid$ Mm.. What time?

M2 Are you going to |see 'Romper Stomper'?

F1 |I think it's 8 o'clock.

F2 Tonight?

F1 And tomorrow and I think Sunday as well.

M2 Are you going to see 'Romper Stomper'?

F1 [To M2] Oh..one day..[To M1]

|Are they going tonight?

M2 It's crap.

F1

Really?

M2

|It's one of the worst movies I've seen. [A long turn by M2 follows.]

This transcript exemplifies some features that are found in collaborative talk, and that researchers have identified as representative of 'the speaking practices of women' (Coates, 1999, p. 123). Responses to questions, well-timed minimal responses and overlapping speech feature in the text. A significant feature of the recording is the speed with which the interaction involving the women proceeds. Each of the men recorded here uses quite different discursive strategies from the practices of the women. M1 overlaps, but then withdraws, leaving the floor to the women. By contrast, M2's strategies disrupt the women's talk. M2 makes several attempts to take the floor and to change the topic (I saw 'Romper Stomper'; Are you going to see 'Romper Stomper'?). His final, 
stressed repetition of Are you going to see 'Romper Stomper' is acknowledged by F1 (Oh..one day), she does not concede the floor to M2, however, but continues to orient talk towards Chomsky's movie (Are they going tonight?) with F2 and M1. M2 eventually interrupts with the arresting statement It's crap. Here the male speaker makes several micro-incursions in order to gain sole control of the discourse, and takes a long, sole-speaker turn when he does. With this move M2 effectively makes a discursive transition from an inclusive to an exclusive topic, since he has already established that the others have not seen 'Romper Stomper'. His subsequent sole turn has a lecturing tone.

This extract neatly exemplifies the contest between cooperative and competitive styles, and illustrates the way in which the competitive style typically succeeds. Repetition, loud volume and assertive statements are successful floor-taking devices. Women's silent withdrawal from the floor and their abandoning of their topic may often go unnoticed in casual conversation. Nevertheless control is being exercised, and is successful.

\subsubsection{Invoking Authority: "Mr Chairman, Point of Order"}

In the next transcript a man resorts to even more explicit control strategies to gain the floor. A group of three male and three female participants are talking during an informal supper: (Note 2)

2) F1 You don't you you don't have a soul until you're born.

M They could |put a little-

F2 |You don't? |Are you serious?

M |They |could s-

F3 Anna, that was from the sixties,

that's that's an idea left over from the sixties.

F2 Then why do they protect you know, the foetus?

F? II's around now.

F1 I don't know, I really don't |know.

F2 |Eh (???)

M Hey listen, what are we going to start doing now |about-

F1 |In my

in my in this

M |Mr Chairman, point of order, we're still talking about whether to baptize it not when it gets its soul now I reckon they could stick a straw down here and ... [long turn by $\mathrm{M}$ follows]

The women are engaged in an interactive style of discourse in which simultaneous speech appears unproblematic. There is no evidence that the women's utterances go unheard, or that their contributions are not attended to. F2 and F3 speak together (F2: Are you serious?; F3: Anna, that was from the sixties, that's that's an idea left over from the sixties; F2: Then why do they protect you know, the foetus?) and F? comments on F3's utterance with It's around now during F1's response (I really don't know) to her question, before she replies to F1. The women weave topics together in a weblike structure. M makes several attempts to gain the floor: They could put a little-; They could s-, trying to command attention with Hey listen, but again abandoning his utterance (what are we going to start doing now about-). The performances of the women in this example and the previous one display quite different strategies from Fishman's $(1978,1983)$ and Spender's (1980a) early descriptions of mixed-sex talk. Here the women are attempting to keep talking on their topic and resisting handing the floor over to the man, rather than talking until they find a topic that the men are interested in and encouraging them to talk, as in Fishman's and Spender's data. The women's behaviour in these data may be interpreted as resisting prescribed gender-appropriate performances and this resistance may be a factor that drives the man's attempts to appropriate the floor and the topic.

M's first explicit challenge is his Hey listen. This seems to mark a number of issues as problematic for him: the women's domination of the discourse; the need for a sole-speaker turn in order for an utterance to be recognized as officially part of the discussion, and the problem for hearing or comprehension if an utterance is spoken in overlap. Listen, he says, trying to command attention and have his problem recognized. He then continues to talk, using a 'Wh' question: (what are we going to start doing now about-) as a topic-controlling device. (Note 3) The women do not readily abandon their style or the floor. In this respect transcripts 1) and 2) are similar. Both transcripts demonstrate women performing collaborative floors and arguably demonstrating solidarity and 
strength in their continued floor-holding. In 2) F1 attempts to continue, even after M's quite explicit intervention strategy. She uses repetition, which was usually a successful floor-taking or floor-holding strategy when used by men in the data. In my in my in this, says F1. However, this strategy does not work for her. She is challenged and silenced by M's appeal to an absent male authority (Mr Chairman). (Note 4) Using loud volume and heavily stressed syllables (Mr Chairman, point of order) M moves from a conversational style to the official register of the boardroom. The male speaker here asserts what the topic should be (we're still talking about whether to baptize it not when it gets its soul), effectively invoking the rules and authority of official discourse to control what he apparently considers to be an aberrant conversational style: it is a style which fails to grant him a sole-speaker turn and permits an unsanctioned topic shift which he marks as 'disorderly'.

While informal conversation may be the 'supergenre' from which other forms select (Heritage, p.c.), formal discursive strategies are incorporated into casual conversation. In transcript 2) there is an explicit example of the appropriation of a formal discourse marker to control informal talk. The use of authorized institutionalized discourse markers both helps to strengthen the power of the control strategy and arguably also validates control. By appropriating a strategy from public discourse in which the relationship between discourse and power is made 'conspicuous' (Baxter, 2003, p. 9), this speaker makes his interactional power evident.

In these examples women are silenced by a range of strategies, and while the strategies, such as the invoking of the authority of 'Mr Chairman' may appear overt, what is arguably concealed is that not only are the women silenced, but that their talk, and significantly, their ways of talking, are effectively condemned as aberrant. The accepted norm is the linear, individualistic turn.

\subsection{The Need for Escalation}

A different reading of examples 1) and 2) could argue that in each text a topic that is introduced is ignored by the other speakers, requiring an escalation of the force of utterances so that an appropriate response is gained (cf Schegloff's (1997) discussion of agreements). In 1), when M2's statement I saw Romper Stomper is not acknowledged, he reintroduces the topic as a question: Are you going to see 'Romper Stomper'? and receiving no response, repeats his question with loud speech on 'Romper Stomper'. This gains a somewhat dismissive response from F1: Oh..one day. before she addresses a comment on the original topic to M1. The majority of this text is overlapping talk between the women. M2 is unsuccessful in changing the topic, and his contributions are minimally acknowledged until he arrests the talk with It's crap. This account of the data highlights the failure of the other interactants to acknowledge M2's contributions, and his need to progressively escalate the force of his utterances. This analysis arguably also demonstrates the level of resistance to regulatory norms in which the women engage. And it shows that despite their resistance, their refusal to abandon their topic or their shared floor, M2's strategies are ultimately successful and he takes a long, sole-speaker turn on a topic on which he is an authority.

A similar pattern can be seen in 2) in which M's utterances are ignored by the women in the conversation. M upgrades his attempts to gain a response with Hey listen, what are we going to start doing now about- which still gains no response, and is interrupted by F1's In my in my in this as she attempts to retain the floor. In a somewhat similar move to transcript 1), the speaker here has to draw on a strategy that will arrest the overlapping talk of the women, so that his contributions are recognised. When M says Mr Chairman, point of order, with loud speech and invoking the institutionalized rules of discourse, his topic and right to a sole speaking turn are acknowledged, and he gains the floor.

This analysis again focuses on the expectation that a contribution should be acknowledged, and if it is not, escalation of the force of the utterance may be expected. This reading foregrounds the needs that any speaker has in an interaction. However, as in 1), this analysis also serves to highlight the level of the resistance of the women to abandoning their speaking style and their topic. In both of these examples we see 'moments when women's voices interrupt the dominant discourse and subversive identities break through' (Bucholtz, 1999, p. 6). The eventual outcome in these data, however, is that the women's subversive practices are silenced, and the men take long sole-speaker turns. We see here both efforts at resistance to heterosexual normative femininity (see Coates, 1999, p. 123), and the resistance that transgression meets (cf Bucholtz 1999, p. 9). These examples and these different analyses exemplify some of the ways in which 'difference' and 'dominance' are 'at play at every moment of interaction' (Tannen, 1999, p. 222). 


\subsection{Explicit Sanctions}

\subsubsection{Metacomments and Withdrawal}

Zimmerman and West (1975, pp. 123-124) find that negative sanction of interruption only occurs in their data in a male-male segment, while women do not complain, even after repeated interruptions. In my data, it is men who provide negative sanction of interruption, and the sanctions are more frequent in the mixed-sex talk than in the all-male conversation. This is probably partly because overlap is more frequent in mixed-sex than in all-male talk, since simultaneous speech is stylistically acceptable for most women and they extend its use from all-female to mixed-sex conversation. Men are also more likely to use overtly controlling strategies in conversations with women because they are drawing on their greater socialized power. Men may also need to use overt strategies more often with women than they do with other men, precisely because women do not immediately recognize that their overlapping speech is causing a problem.

Some of the metacomments made by men to women in the data collected for this study are Let me finish; I hadn't finished what I was saying; I let you say what you think, now you must let me say my bit; What I was trying to say before. All of these comments relate to perceived flaws in the discourse arising out of the overlapping of a male turn by a female turn. The metacomments indicate that males' speaking space has been penetrated. Overlaps are apparently interpreted by male speakers as violations of the 'ideal sphere' which surrounds and protects them (Simmel, 1950, p. 321). Like Coates (1996, p. 140) this researcher found no recorded data in the study showing women objecting to overlapping speech as interruption (see also Edelsky, 1981, p. 391).

It was not always the case that men challenged women's interactional behaviour, and took the floor, silencing the woman or women. Performances that were interpreted as 'incorrect' or as deviating from communicative norms sometimes resulted in the silence or even withdrawal from the interaction of the male participant. Such action may function as a powerful punitive mechanism.

In transcript 3) M1 (Paul), and a woman are talking at a café when M2 (Tony) approaches the table. M2 is an acquaintance of both the original speakers.

3) M1 I played tennis last night, then we went to the club

|house-

F [to M2] $\mid \mathrm{Hi}$, Tony, oh Paul [to M1] it was so funny the other day, I was here with these two women and Tony said-

M1 I'm going to get a coffee. [goes inside cafe]

F [to M2] Sorry, I'd better go and see what's the matter.

When M1 and F return to the table, M1 says You interrupted me. I was in the middle of a sentence when you spoke. That was rude. F explains that she wanted to include M2. M1 reiterates that her interruption was rude and the woman does not speak for the remaining 11 minutes of recording.

This interaction may be viewed as one micro-instance of the differential linguistic expectations of women and men and the systems of control and domination that support these differences. Schutz (1962, p. 55) states that many features of everyday interaction are taken for granted by social actors. In regard to the interactive event under discussion, the meanings of some of these 'taken-for-granted' features, (for instance, that interruption is rude; women's behaviour can and should be controlled), are exposed by the man's metacomments.

The most usual pattern in these data is that women responded to a man's silent withdrawal from conversation by granting him the floor. This interpretation is confirmed by the fact that a woman often preceded her withdrawal by an apology, as demonstrated in the following transcript.
4) $\mathrm{M}$
When we went to Warwi|ck-
F
But some of them are-.. sorry.
M When we went to Warwick I took some.

Here the female speaker commences an overlapping utterance but the man's cessation of speech appears to signal to her that she is intruding on his turn. She stops abruptly, apologizes for what she apparently interprets as inappropriate behaviour, and withdraws from the speaking floor. Sorry here is a repair mechanism (cf Sacks, Schegloff \& Jefferson, 1974), and it highlights the notion that overlapping speech is perceived as 'deviant' by some speakers. The problematic nature of F1's overlap is confirmed by the fact that the man repeats his utterance. 
When women behave in ways that men perceive as inappropriate, male silence may force women to withdraw from the floor. By contrast, men do not seem to interpret women's silence as problematic. When a woman abruptly stops speaking because she has been silenced by a man's speech, the continuation of the male's sole-speaker turn suggests that silence was an appropriate response. There are no instances in these data of a man questioning a woman's withdrawal from the floor in these types of situations.

Talbot (1992, p. 459) draws attention to the need to do more than count syllables: discoursal activity must be analyzed in order to uncover the differential notions of turn-taking rights and distributions held by participants. This paper reveals these differences, and shows how participants come to understand what their rights are, and how they behave when they reach this understanding. We have seen that silent withdrawal by men is a means of censuring what is perceived by them as women's inappropriate behaviour, and we have also observed women's recognition of this criticism, and their resultant silence. Talbot (1992) describes a situation in which a husband talks more than his wife but still feels that her contributions are violations of his speaking rights. I wish you'd stop interrupting me is his response to her contributions to his story. After this remark, says Talbot, the other participants contribute significantly less. In Talbot's example, metalinguistics are used as a silencing strategy.

The behaviour described by Talbot occurs repeatedly in the mixed-sex data in this study. In one recording a man reacts to a woman's responses by saying:

5) I'd like you to listen to what I say and then respond to my argument rather than make comments along the way. ... Are you prepared to do this? ... Can you do this?

As in Talbot's (1992) example, the result is the silencing of the female speaker. It is interesting that both speakers adhere to an assumption that a general norm operates to control behaviour.

\subsubsection{Micro-societal control}

This type of silencing has repercussions beyond each instance of a single interactive event. Wider social control can be exercised through micro-interaction. And at a personal, individual level, each interactional event can be personally constructive or destructive. In transcript 6) a woman describes how her male house-mate has attacked her conversational behaviour. He had blamed her failure to sustain relationships with men on what he termed her 'linguistic incompetence'.

6) F1 He said I'm very dominating and rude in conversation. He says I'm always interrupting and won't let him get a word in.

F2 I don't think you're dominating and rude!

F1 No, well, it's alright when I'm talking to women. I do talk a lot, but when I'm with women|it's

It's fun.

F1 Yeah, it's fun.. But when I'm talking to men..they don't like it. I try to stop interrupting when I'm with men.

So, while women feel that their ways of behaving and thinking are valid, they consistently receive evidence that their behaviour is invalid and deviant. This transcript exemplifies the claim made by Belenky, Clinchy, Goldberger and Tarule (1986, p. 48) that women look to others' definitions of their own identity. As a woman college student in their study says, 'You get a pretty good idea of yourself from the comments that other people are saying about you'. While the comments people make may be directed towards single behavioural acts, ultimately, the general self-esteem of the actor is affected.

The above example demonstrates this process: F1's conversational behaviour is negatively evaluated by a male (she interrupts); this devaluation extends to her more general social competence (she has problems with relationships with men), and her personality (she is dominating and rude). While she receives negative evaluation from a male, her behaviour is validated by the female (I don't think you're dominating and rude!), and the overlapping duet: F1 when I'm with women it's fun F2 It's fun. F1 Yeah, it's fun affirms the value of their shared talk (cf Falk, 1980). Arguably, the man's comments will be assumed to have more value, since he is speaking from a position of institutionalized power. Goffman's (1961, p. 41) description of the power of others to create or destroy the self is insightful:

There seems to be no agent more effective than another person in bringing a world for oneself alive or, by a glance, a gesture, or a remark, shriveling up the reality in which one is lodged.

One important feature of the analysis carried out here is that it takes into account silences and abstention from 
action. Women's silencing is widely discussed by gender and language theorists (e.g., DeFrancisco, 1991; Herring et al., 1992, 1995; Lakoff, 1995; Spender, 1980a,b, 1982; West,, 1995; see also discussion of silence in Speer, 2005; West, Lazar \& Kramarae, 1997), and by psychologists (e.g., Belenky et al., 1986). The relationship of these arguments to the sociological theory is generally unremarked, despite the fact that sociology's insights can highlight important aspects of gender-related interactional behaviour. For example, Schutz objects to the neopositivists' sociological approach on the basis that its emphasis on observable behaviour overlooks "'negative actions," i.e., intentional refraining from action' (1973, p. 54). Another aspect connected with the neopositivist treatment of social science in terms of sensory observation and overt action that Schutz (1973, p. 54) finds problematic is that it excludes 'beliefs and convictions which are real because they are so defined by the participants and which escape sensory observation'. Schutz's comments have implications for the data presented here. The silent withdrawal of men or women from discursive interaction is a highly meaningful feature of each interactive event that could be overlooked by a concentration on observable action which ignores failure to act or cessation of action. Schutz's remarks in relation to the collective definition of beliefs and convictions and their consequences are also significant to the analysis of these data. These two comments of Schutz are brought together here because of their particular relevance for conversational interaction: the consequence for women of their failure to observe the collectively 'real' beliefs of the mixed-sex speech community is either their silence or the silence of their male interactants. Ultimately, the consequence of inappropriate behaviour is the real consequence that it will be considered deviant. Women who 'misbehave' are judged and silenced.

The data thus demonstrate consequences related to the collective definition of 'real beliefs and convictions'. One of the most important issues revealed by the analysis of the data is that male beliefs were collectively given normative value and that men actively controlled the discursive style. Men's cessation of speech is a means of subtly controlling the discourse which often goes unobserved, both by social actors and by theorists. Linguistic forms such as 'sorry' may also have a controlling power that is obscured by their more overt function. In these data women usually say 'sorry' and withdraw from the floor when they have overlapped a male speaker, while men typically say 'sorry' when they overlap, and continue to speak. The use of apologies is not the refraining from action which Schutz discusses, but is arguably a similar phenomenon: it produces the required reaction from the other speaker while concealing the strategy which generates this reaction. The failure to act or the concealing of controlling strategies are meaningful features of dominant practices.

\subsection{Uncovering the Rules}

Denzin (1971, p. 271) claims that ethnomethodology is concerned with 'the penetration of normal situations of interaction to uncover the rules and rituals participants take for granted': a characterization that is contested by Zimmerman and Wieder who argue that their interest is with the 'ways that members assert that there are rules that have been, are, and will control their action' (1971, p. 294). It may be suggested that these are not necessarily separate activities, but that each can usefully comment on the other. This project shows the relationship between 'uncovering' the rules that participants take for granted and the 'ways that members assert that there are rules': participants' performances uncover the underlying rules to which they are appealing. These data show that there is an expectation that the sole-speaker turn should be normative in mixed-sex and all-male conversation. This expectation is treated as a rule that is invoked to censure overlapping speech.

This study exposes the significance of a further assertion made by Zimmerman and Wieder. They claim that they are not, as Denzin (in Zimmerman \& Wieder, 1971, p. 294) suggests, concerned with issues such as 'How do interactional rules emerge and How is stable social action possible?'. Ethnomethodology is concerned instead with 'How do persons make a rule emergent and how do they use it?. How do persons see and describe social action as stable?' (Zimmerman \& Wieder, 1971, p. 294). In the case of turn-taking and overlapping speech 'the rule is made emergent' by implicit and explicit negative sanction of deviation. People use the rule both by sanctioning deviant behaviour and by undertaking reparative action when negative sanction is recognized. In each individual interactive situation stability of action is generally ensured by the availability of a rule, and by the availability of ways of imposing it. To the extent that the rules are used and are effective, they maintain a degree of stability of social action in each interactive event. Since each event forms part of a wider, socially accepted discursive practice, it helps to maintain the stability of a wider social performance, and this may include an androcentric status quo.

\section{Conclusion}

The application of a range of theoretical positions and interdisciplinary insights allows a thorough examination of interactional behaviours. The analysis of conversational data shows the salience of overlap and interruption, and the normative value of the sole-speaker turn in mixed-sex talk. Performances that vary from a taken for 
granted model may be censured. The data show the negative linguistic sanction of women's voices, and this sanction draws attention to the salience of power, status and gender in everyday conversation. Micropolitical enactments in mixed-sex conversation work to normalize gendered social constructs and reinforce traditional arrangements between the sexes, with women's voices of resistance being silenced. Women's voices do interrupt the dominant discourse (Bucholtz, 1999, p. 6), and there are 'moments of powerfulness within' as well as 'in the spaces between' discourses (Baxter, 2003, p. 39) when women observe the minutiae of performances, and refuse to engage with dominant practices. The data and analysis show that difference and dominance are constantly at play in interaction and are suggestive of the value of an inclusive approach to theory. The performances in this study highlight the need for ongoing feminist engagement. This article, like Coates's (1999, p. 124) research,

challenges the notion that we live in a postfeminist era, that women's struggles are over.

\section{Acknowledgements}

My grateful thanks go to all the people who participated in the study.

\section{References}

Abu-Lughod, L. (1990). The romance of resistance: Tracing transformations of power through Bedouin women. American Ethnologist, 17, 41-55.

Aries, E. (1996). Men and Women in interaction: Reconsidering the difference. New York: Oxford University Press.

Aries, E. (1997). Women and men talking: Are they worlds apart? In M. R. Walsh (Ed.), Women, Men and Gender. Ongoing Debates (pp. 91-100). New Haven, C.T. \& London: Yale University Press.

Baxter, J. (2003). Positioning Gender in Discourse. A Feminist Methodology. Basingstoke: Palgrave Macmillan.

Belenky, M. F., Clinchy, B. M. V., Goldberger, N. R., \& Tarule, J. M. (1986). Women's Ways of Knowing: The Development of Self, Voice, and Mind. New York: Basic Books.

Brown, P. (1990). Gender, politeness and confrontation in Tenejapa. Discourse Processes, 13, 123-141.

Bucholtz, M. (1999). Bad Examples: Transgression and Progress in Language and Gender Studies. In M. Bucholtz, A. C. Liang, \& L. A. Sutton (Eds.), Reinventing Identities: The Gendered Self in Discourse. New York \& Oxford: Oxford University Press.

Bucholtz, M., Liang, A. C., \& Sutton, L. A. (Eds.). (1999). Reinventing Identities. The Gendered Self in Discourse. New York \& Oxford: Oxford University Press.

Butler, J. (1990a). Gender trouble: Feminism and the subversion of identity. New York: Routledge.

Butler, J. (1990b). Performative acts and gender constitution: An essay in phenomenology and feminist theory. In S. Case (Ed.), Performing feminisms: Feminist critical theory and theatre (pp. 270-282). Baltimore: Johns Hopkins University Press.

Butler, J. (1997). Excitable Speech: A Politics of the Performative. New York: Routledge.

Coates, J. (1986). Women, Men and Language. London: Longman.

Coates, J. (1989). Gossip revisited. Language in all-female groups. In J. Coates, \& D. Cameron (Eds.), Women in Their Speech Communities (pp. 94-122). London; New York: Longman.

Coates, J. (1996). Women Talk. Oxford: Blackwell.

Coates, J. (1999). Changing Femininities: The talk of teenage girls. In M. Bucholtz, A. C. Liang, \& L. A. Sutton (Eds.), Reinventing Identities. The Gendered Self in Discourse (pp. 123-144). New York \& Oxford: Oxford University Press.

Coates, J., \& Cameron, D. (Eds.). (1989). Women in Their Speech Communities. London: Longman.

Cook-Gumperz, J. (1992). Gendered talk and gendered lives: Little girls being women before becoming (big) girls. In K. Hall, M. Bucholtz, \& B. Moonwomon (Eds.), Locating Power 1, Proceedings of the second Berkeley women and language conference, April 4 and 5 (pp. 68-79). Berkeley, Cal.: Berkeley Women and Language Group.

Cook-Gumperz, J. (1995). Reproducing the discourse of mothering: How gendered talk makes gendered lives. In K. Hall, \& M. Bucholtz (Eds.), Gender Articulated (pp. 401-419). New York: Routledge.

Crawford, M. (1995). Talking Difference: On Gender and Language. London: Sage. 
DeFrancisco, V. L. (1991). The sounds of silence: How men silence women in marital relations. Discourse and Society, 2, 413-423.

Denzin, N. K. (1971). Symbolic interactionism and ethnomethodology. In J. D. Douglas (Ed.), Understanding Everyday Life (pp. 259-284). London: Routledge \& K. Paul.

Eakins, B. W., \& Eakins, R. G. (1978). Sex differences in human communication. Boston, MA: Houghton Mifflin.

Edelsky, C. (1981). Who's got the floor? Language in Society, 10, 383-421.

Falk, J. (1980). The conversational duet. Proceedings of the 6th annual meeting of the Berkeley Linguistics Society, 6, 507-514.

Fishman, P. (1978). Interaction: The work women do. Social problems, 25, 397-406.

Fishman, P. (1983). Interaction: The work women do. In B. Thorne, C. Kramarae, \& N. Henley (Eds.), Language, Gender and Society (pp. 89-101). Rowley, Mass.: Newbury House.

Freed, A., \& Greenwood, A. (1996). Women, men and type of talk: What makes the difference? Language in Society, 25(1), 1-26.

Garfinkel, H. (1967). Studies in Ethnomethodology. Englewood Cliffs: Prentice Hall.

Goffman, E. (1961). Encounters: Two Studies in the Sociology of Interaction. Indianapolis: Bobbs-Merrill.

Graddol, D., \& Swann, J. (1989). Gender Voices. Oxford: Basil Blackwell.

Harding, S. (1986). The Science question in Feminism. Milton Keynes: Open University Press.

Henley, N. (1977). Body Politics. Power, sex and nonverbal communication. Englewood Cliffs, NJ: Prentice Hall.

Herring, S., Johnson, D. A., \& DiBenedetto, T. (1992). Participation in electronic discourse in a "feminist" field. In K. Hall, M. Bucholtz, \& B. Moonwomon (Eds.), Locating Power 1: Proceedings of the second Berkeley women and language conference, April 4 and 5 (pp. 250-262). Berkeley, Cal.: Berkeley Women and Language Group.

Herring, S., Johnson, D. A., \& DiBenedetto, T. (1995). "This discussion is going too far!": Male resistance to female participation on the internet'. In K. Hall, \& M Bucholtz (Eds.), Gender Articulated: Language and the Socially Constructed Self (pp. 67-96). New York: Routledge.

Hirschman, L. (1973). 'Female-male differences in conversational interaction'. Paper presented at Linguistic Society of America. In B. Thorne, \& N. Henley (Eds., 1975), Language and Sex: Difference and Dominance. Rowley, MA: Newbury House.

Hodge, R., \& Kress, G. (1988). Social Semiotics. Cambridge: Polity in association with Basil Blackwell.

Holmes, J. (1984). Hedging your bets and sitting on the fence: Some evidence for hedges as support structures. Te Reo, 27, 47-62.

Holmes, J. (1986). Functions of You Know in Women's and Men's Speech. Language in Society, 15(1), 1-22.

Holmes, J. (1995). Women, Men and Politeness. London: Longman.

Keenan, E. (1974). Norm-makers, norm-breakers: Uses of speech by men and women in a Malagasy community. In R. Bauman, \& J. Sherzer (Eds.), Explorations in the Ethnography of Speaking (pp. 125-143). Cambridge: Cambridge University Press.

Lakoff, R. (1975). Language and Woman's Place. New York: Harper \& Row.

Lakoff, R. (1995). Cries and whispers: The shattering of the silence. In K. Hall, \& M. Bucholtz (Eds.), Gender Articulated (pp. 25-50). New York: Routledge.

Leet-Pellegrini, H. M. (1980). Conversational dominance as a function of gender and expertise. In H. Giles, P. Robinson, \& P. Smith (Eds.), Language: Social psychological perspectives (pp. 97-104). Oxford: Pergamon.

Lorber, J., \& Farrell, S. A. (Eds.). (1991a). The Social Construction of Gender (pp. 7-11). Newbury Park: Sage.

Lorber, J., \& Farrell, S. A. (Eds.). (1991b). The Social Construction of Gender (pp. 1-6). Newbury Park: Sage.

Maltz, D. N., \& Borker, R. A. (1982). A cultural approach to male-female miscommunication. In J. J. Gumperz (Ed.), Language and Social Identity (pp. 196-216). New York: Cambridge University Press. 
O’Barr, W. M., \& Atkins, B. K. (1980). 'Women's language' or 'powerless language'? In S. McConnell-Ginet, R. Borker, \& N. Furman (Eds.), Women and Language in Literature and Society (pp. 93-110). New York: Praegar.

Pauwels, A. (1998). Women Changing Language. New York: Addison Wesley Longman.

Peck, J. J. (2000). The mutual process of semioticization: Linguistic acquisition and performance of social subjectivities. Australian Journal of Linguistics, 20, 179-209.

Peck, J. J. (2006). Women and promotion: The Influence of Communication Style. In M. Barrett, \& M. J. Davidson (Eds.), Gender and Communication at Work (pp. 50-66). Aldershot: Ashgate.

Sacks, H., Schegloff, E. A., \& Jefferson, G. (1974). A simplest systematics for the organization of turn-taking for conversation. Language, 50, 696-735.

Schegloff, E. A. (1997). Whose text? Whose context? Discourse and Society, 9(3), 413-416.

Schutz, A. (1962). Collected Papers (Vol. I). The Hague: Martinus Nijhoff.

Schutz, A. (1973). Collected Papers (Vol. I). The Hague: Martinus Nijhoff.

Sheldon, A. (1996a). Pickle fights: Gendered talk in preschool disputes. Discourse processes, 13, 5-31.

Sheldon, A. (1996b). You Can be the Baby Brother, But You Aren't Born Yet: Preschool girls' negotiation for power and access in pretend play. Research on language and social interaction, 29(1), 57-80.

Simmel, G. (1950). The Sociology of Georg Simmel (K. H. Wolff, Ed.). Glencoe, III.: Free Press.

Speer, S. A. (2005). Gender Talk. Feminism, Discourse and Conversation Analysis. London: Routledge.

Spender, D. (1980a). Man Made Language. London: Routledge \& K. Paul.

Spender, D. (1980b). Talking in class. In D. Spender, \& E. Sarah (Eds.), Learning to Lose (pp. 148-154). London: The Women's Press.

Spender, D. (1982). Invisible Women. London: Writers and Readers.

Talbot, M. (1992). "I wish you'd stop interrupting me!”: Interruptions and asymmetries in speaker-rights in equal encounters. Journal of Pragmatics, 18, 451-466.

Tannen, D. (1987). That's Not What I Meant! How Conversational Style Makes or Breaks Relationships. New York: Ballantine.

Tannen, D. (1989). Talking Voices: Repetition, Dialogue and Imagery in Conversational Discourse. Cambridge: Cambridge University Press.

Tannen, D. (1990). You just don't understand: Women and Men in Conversation. New York: Ballantine Books.

Tannen, D. (1999). The display of (Gendered) Identities in talk at work. In M. Bucholtz, A. C. Liang, \& L. A. Sutton (Eds.), Reinventing Identities, The Gendered Self in Discourse (pp. 221-240). New York \& Oxford: Oxford University Press.

Tannen, D., \& Saville-Troike, M. (Eds.). (1985). Perspectives on Silence. Norwood, N.J.: Ablex.

Thorne, B. (2001). Gender in Interaction: Widening the Conceptual Scope. In H. Kotthoff, \& B. Baron (Eds.), Gender in Interaction: Perspectives on femininity and masculinity in ethnography and discourse (pp. 3-18). Amsterdam \& Philadelphia: John Benjamins.

Thorne. B., Kramarae, C., \& Henley, N. (Eds.). (1983). Language, Gender, and Society. Rowley, MA: Newbury House.

Uchida, A. (1992). When 'difference' is 'dominance': A critique of the 'anti-power-based' cultural approach to sex differences. Language in Society, 21, 547-568.

Weatherall, A. (2002). Gender, language and discourse. Hove: Routledge.

West, C. (1984). When the doctor is a lady. Symbolic interaction, 7(1), 87-106.

West, C. (1995). Women's competence in conversation. Discourse and Society, 6, 107-131.

West, C., Lazar, M., \& Kramarae, C. (1997). Gender in discourse. In T. A. van Dijk (Ed.), Discourse as Social Interaction. Discourse Studies: A Multidisciplinary Introduction, 2 (pp. 119-143). London: Sage.

West, C., \& Zimmerman, D. H. (1991). Doing gender. In J. Lorber, \& S. A. Farrell (Eds.), The Social Construction of Gender (pp. 13-37). Newbury Park: Sage. 
Zimmerman, D. H., \& West, C. (1975). Sex roles, interruptions and silences in conversation. In B. Thorne, \& N. Henley (Eds.), Language and Sex. Difference and Dominance (pp. 105-129). Rowley, Mass.: Newbury House.

Zimmerman, D. H., \& Wieder, D. L. (1971). Ethnomethodology and the problem of order: Comment on Denzin. In J. D. Douglas (Ed.), Understanding Everyday Life (pp. 285-298). London: Routledge \& K. Paul.

\section{Notes}

Note 1. Keenan (1974), Brown (1990), and Abu-Lughod (1990) discuss gender-differential performances in a range of cultural settings. Keenan (1974) demonstrates the association of highly valued linguistic features with male speech.

Note 2. Although I was told that there were three men present, one man never spoke during the 90 minutes of recorded data. During another 90 minute recording of one woman and two men, one of the men did not speak. The socialization of males into hierarchical discursive positions may produce many highly competitive men, while others may be intimidated or may have rejected conventionally expected strategies.

Note 3. Fishman (1983) comments on the effectiveness of questions to obtain responses when a speaker is being ignored. Hey listen here seems to function in the same way. In Fishman's data women are the principal users of these devices, which indicates the markedness of the man's need to use this strategy in this conversation.

Note 4. This strategy occurs elsewhere in data recorded for this study of a mixed-sex group in their twenties. One man successfully arrested the women's animated overlapping talk by saying 'Point of order, Mr Chairman'.

\section{Appendix}

\section{Transcription conventions}

$\mathrm{F} 1, \mathrm{~F} 2$ = female speaker 1 , female speaker 2, etc.

M1, M2 = male speaker 1, male speaker 2, etc.

.. indicates a short pause

... indicates a longer pause

indicates an incomplete or abruptly stopped utterance

(?) Unclear speech, or unidentified speaker

Emphatic or loud speech is indicated by bold text

indicates overlapping or simultaneous speech

e.g., know, and we'd

Know and we'd | laugh

| be laughing

Square brackets are placed around extra information, e.g., [laughter]; [no response]

\section{Copyrights}

Copyright for this article is retained by the author(s), with first publication rights granted to the journal.

This is an open-access article distributed under the terms and conditions of the Creative Commons Attribution license (http://creativecommons.org/licenses/by/3.0/). 